\title{
Cheatham-Platinum stent for native and recurrent aortic coarctation in children and adults: immediate and early follow-up results
}

\author{
Nativ ve yineleyici aort koarktasyonu olan erişkin ve çocuklarda Cheatham-Platinum stenti: \\ Erken ve kısa dönem takip sonuçları
}

\author{
Abdullah Erdem, Celal Akdeniz, Türkay Sarıtaş, Nurdan Erol, Fadli Demir, Ali Rıza Karaci*, \\ Yalım Yalçın ${ }^{1}$, Ahmet Çelebi
}

From Departments of Pediatric Cardiology and *Cardiovascular Surgery, Dr. Siyami Ersek Thoracic and Cardiovascular Surgery Center, İstanbul ${ }^{1}$ Department of Pediatric Cardiology, Medicana International Hospital, İstanbul-Turkey

Objective: To present our institutional experience of endovascular Cheatham-Platinum stent implantation in children and adults with native and recurrent aortic coarctation.

Methods: Between August 2007 and November 2009, 45 patients had aortic coarctation treated with 47 stents implantation. We preferred primarily stent implantation in adult patient with coarctation, in children more than five years-old it is preferred in cases of aneurysm, subatretic or blind coarctation and coarctation with patent ductus arteriosus or in restenosis. Files of stent-implanted patients were retrospectively analyzed in terms of patients' demographic features, echocardiographic and angiographic findings both before and after procedure. Patients grouped as Group 1: native coarctation and Group 2: recoarctation developed after either surgery or balloon angioplasty. Findings of the cases' were compared using paired and unpaired Student's t, Mann-Whitney U and Chi-square tests.

Results: Sixteen covered and 31 bare totally 47 balloon expandable stents were implanted in 45 patients. The mean follow up duration was $12.1 \pm 7.1$, median 11 months (2-29 months). There was no procedure related death. In two patients two stents were implanted in tandem. While the coarctation of the aorta was native in 26 patients (functionally interrupted aortic arch in one), recoarctation was detected in 7 patients after surgery, in 8 patients after balloon angioplasty, in 4 patients both after surgery and balloon angioplasty. One patient had functionally interrupted aortic arch perforated with guide wire and then covered stent implanted. The mean age $12.2 \pm 5.9$ years (5-33 years) and mean body mass index was $21 \pm 3.7 \mathrm{~kg} / \mathrm{m}^{2}\left(14.8-31 \mathrm{~kg} / \mathrm{m}^{2}\right)$. Considering all cases, a statistically significant decrease in both the invasive and echocardiographic gradients $(p<0.001$ for both) and statistically significant increase in lesion diameter $(p<0.001)$ were detected. The decrease in invasive and echocardiographic gradients and increase in lesion diameter is statistically significant in each group also ( $p<0.001,<0.001$ and $<0.001$ for both groups, respectively). Before the procedure, the invasive gradient was significantly higher and the lesion diameter was significantly lower in group I than in group II ( $p=0.002$ and $p=0.005$, respectively). Also the percentage of decrease in gradient and increase in diameter was statistically higher in group 1 than in group 2 ( $p=0.04$ and $p=0.04)$.

Conclusion: Our early and short- term follow-up results indicate that stent implantation is safe and very effective in reducing coarctation gradient and increasing lesion diameter both in native coarctation and recoarctation. (Anadolu Kardiyol Derg 2011; 11: 441-9)

Key words: Cheatham-Platinum, stent, aortic coarctation, follow-up

\section{ÖZET}

Amaç: Yetişkin ve çocuklarda Cheatham-Platinum stent implantasyonu ile tedavi edilen nativ ve rekürren aort koarktasyonu olgularının erken ve kısa dönem sonuçlarını sunmayı amaçladık.

Yöntemler: Ağustos 2007-Kasım 2009 tarihleri arasında 45 hastaya 47 stent yerleştirildi. Koarktasyon tanısı alıp müdahale endikasyonu olan adölesan ve yetişkin hastalarda ilk tercih olarak, 5 yaş üzerindeki çocuklarda ise subatretik veya kör koarktasyon varlı̆̆ı önceki tedaviye bağlı anevrizma gelişimi, eşlik eden patent duktus arteriyozus veya yeniden daralma durumlarında stent implantasyonu tercih edildi. Stent implantas-

Address for Correspondence/Yazışma Adresi: Dr. Abdullah Erdem, Department of Pediatric Cardiology, Dr Siyami Ersek Thoracic and Cardiovascular Surgery Center, 34672 İstanbul-Turkey Phone: +90 2165424604 Fax: +90 2164189677 E-mail: drabdullaherdem@hotmail.com

This study was partly presented at the gth National Congress of Pediatric Cardiology and Cardiovascular Surgery, 5-8 May 2010, Eskişehir, Turkey

Accepted Date/Kabul Tarihi: 02.03.2011 Available Online Date/Çevrimiçi Yayın Tarihi: 29.06.2011

(C) Telif Hakkı 2011 AVES Yayıncılık Ltd. Şti. - Makale metnine www.anakarder.com web sayfasından ulaşılabilir.

(C) Copyright 2011 by AVES Yayıncillk Ltd. - Available on-line at www.anakarder.com doi:10.5152/akd.2011.112 
yonu gerçekleştirilen olguların dosyaları retrospektif olarak işlem öncesi ve sonrası hastaya ait özelikler ve takip bulguları açısından detaylı olarak incelendi. Olgular nativ koarktasyon (Grup 1) ve balon anjiyoplasti veya cerrahi sonrası rekoarktasyon (Grup 2) olarak gruplandırıldı. Olgulara ait bulgular eşleştirilmemiş ve eşleştirilmiş Student t, Mann-Whitney U ve Ki-kare testleri ile karşılaştırıldı.

Bulgular: On altısı kaplı, 31'i çıplak olmak üzere 45 hastaya 47 Cheatham-Platinum stent implantasyonu gerçekleştirildi. Olguların ortalama takip süresi $12.1 \pm 7.1$, medyan 11 ay (2-29 ay) idi. Işleme bağlı mortalite gelişmedi. Iki hastada aynı seansta iki stent konuldu. Aort koarktasyonu 26 hastada nativ iken (1 olguda fonksiyonel olarak kesintili aortik arkus mevcut), 7 hasta cerrahi sonrası, 8 hasta balon anjiyoplasti sonrası, 4 hasta da hem cerrahi hem de cerrahi sonrası takipte balon anjiyoplasti yapılmış ve yeniden rekoarktasyon gelişmiş hastalar idi. Fonksiyonel olarak kesintili aortik arkusu olan olguda, lezyonun kılavuz telin sert ucu ile perforasyonu sonrası kaplı stent implantasyonu gerçekleştirildi. Hastaların ortalama yaşı $12.2 \pm 5.9$ yıl (5-33 yıl) ve ortalama vücut kitle indeksi $21 \pm 3.7 \mathrm{~kg} / \mathrm{m}^{2}$ (14.8-31) bulundu. Tüm olgular göz önüne alındığında işlem sonrasında işlem öncesine göre ortalama invaziv ve ekokardiyografik gradiyentte anlamlı bir azalma ( $<<0.001$ ve $p<0.001$ ), lezyon çapında anlamlı artış $p<0.001)$ tespit edildi. Gradiyentlerdeki azalma ve lezyon çapındaki artış her iki grubun kendi içinde de anlamlı idi ( $p<0.001,<0.001$ ve $<0.001$, her iki grup içinde). Grup 1 olgularında, Grup 2' ye göre işlem öncesi invaziv gradiyent daha yüksek ve lezyon çapı daha düşük saptandı ( $p=0.002$ ve $p=0.005)$. Yine Grup 1 olgularında işlem sonrası yüzde gradiyent azalması ve lezyon çapındaki artış anlamlı olarak daha yüksek bulundu ( $p=0.04$ ve $p=0.04)$.

Sonuç: Işlem sonrası erken dönem ve kısa süreli takip sonuçlarımız stent implantasyonunun koarktasyon gradiyentinin azaltılması ve koarktasyon çapının genişletilmesinde hem nativ koarktasyon hem rekoarktasyon olgularında etkili, güvenli ve uygulanabilir bir yöntem olduğunu düşündürmektedir. (Anadolu Kardiyol Derg 2011; 11: 441-9)

Anahtar kelimeler: Cheatham-Platinum, stent, aort koarktasyonu, takip

\section{Introduction}

Balloon angioplasty (BAP) is widely accepted treatment for patients with native and recurrent coarctation of aorta (reCoA) in patients older than six months (1). But BAP alone can be associated with vessel recoil and recurrence or persistence of the lesion (2). To overcome these problems over distention may be needed which can cause aortic wall injury $(3,4)$. Recently stents have been started to be used in older children and young adults for the primary treatment of both native and reCoA to solve these (5). Initially stents were used only for case where surgery and BAP failed. But with increasing experience, it gradually becomes the treatment of choice in anatomically unfavorable cases for BAP, reCoA, coarctation of aorta $(\mathrm{CoA})$ with patent ductus arteriosus (PDA) and CoA with aneurysm $(6,7)$. CheatamPlatinum (CP) stent is the one of the most commonly used stent in pediatric cardiology which is made from $90 \%$ platinum and $10 \%$ iridium. While it is available 6 and 8 rows mostly used in 8 -zig configuration which could be dilated up to $28 \mathrm{~mm}$. This stent has excellent radial strength even at larger diameters and also has brilliant visibility on fluoroscopy.

In this study, we aimed to present immediate and early results of our experience with $\mathrm{CP}$ stents in children and adults both in native and reCoA.

\section{Methods}

\section{Study design and population}

\section{The study was designed as retrospective analysis}

Between August 2007 and November 2009, 45 patients had CoA had been treated with 47 covered or bare CP stent (NuMED CP stent, Heart Medical Europe BV, Best, the Netherlands) implantation. Diagnosis of reCoA was based upon a combination of clinical signs (arm-leg blood pressure (BP) difference $\geq 20$ $\mathrm{mmHg}$, non-invasive imaging echocardiography, computerized tomography (CT) scan or magnetic resonance imaging (MRI) and/or invasive gradient measurements. We preferred stent implantation primarily in adult patient with $\mathrm{CoA}$ and hyperten- sion (HT). In children above five years old or $20 \mathrm{~kg}$ weight stent implantation is preferred in cases of aneurysm, subatretic or functionally interrupted aortic arch (IAA) and association with patent ductus arteriosus or in reCoA. Covered stents were preferred in patients having aneurismal dilatation, PDA association and atretic or coarctation. Files of stent implanted patients were retrospectively analyzed in terms of patients' demographic features, echocardiographic and angiographic findings both before and after procedure. All the patients were evaluated both before and after procedure in terms of echocardiographic and invasive gradient, coarctation diameter.

Patients grouped as Group 1: native $\mathrm{CoA}$ and Group 2: reCoA and/or aneurysm developed after either surgery or BAP (Table 1).

\section{Echocardiographic evaluation}

Transthoracic echocardiography (Vivid-3, General Electric, Norway) was performed using 3.5 and $5 \mathrm{mHz}$ probes. Coarctation segment was imaged by two-dimensional echocardiography and the peak coarctation gradients were measured with a continuous flow Doppler examination before procedure. Echocardiographic examination also revealed other associated intracardiac lesions. Repeated echocardiographic examinations were performed 24 hours after the procedure and follow-up to evaluate stent localization and the presence of residual gradients.

\section{Catheterization technique}

After detailed explanation, informed written consent was obtained from all adult patients or parents of patients if they were children. All procedures were performed under deep sedation with anesthetic support. As soon as femoral access was obtained patients were heparinized $100 \mathrm{IU} / \mathrm{kg}$ or $5000 \mathrm{IU}$ in adults.

The peak systolic gradient was measured invasively before stent implantation. In 40 of 45 patients the CoA segment was crossed with a hydrophilic guide wire 0.035 inch in diameter; a marker pig-tail catheter was then passed over the wire into the arch of aorta retrogradely. A diagnostic catheterization was performed to determine the exact morphology and the pressure gradient of the stenosis in all patients. Angiography was per- 
Table 1. Baseline patient features

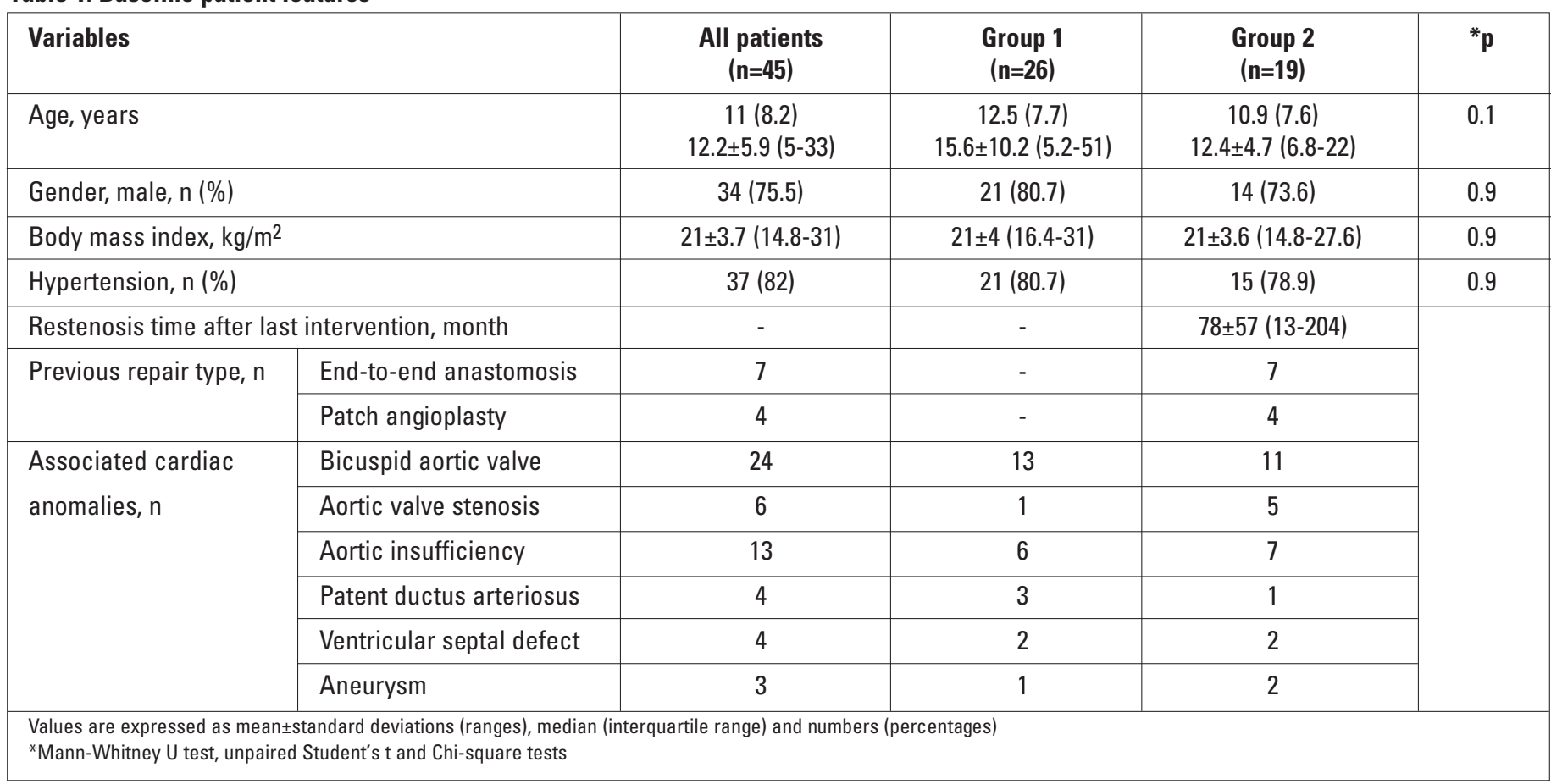

formed lateral and anteroposterior or left anterior oblique positions with this catheter. The aorta was measured at the ascending aorta, transverse arch, isthmus, CoA site, proximal and distal to the obstruction, and at the level of the diaphragm.

Once measurements were made and recorded we decided the appropriate stent and delivery balloon. We used a single balIoon catheter (Zymed, NuMED Inc, Heart Medical Europe BV, Best, the Netherlands) in 18 patients that was equal or slightly longer than the stent length with a diameter no greater than the aortic diameter at the level of the diaphragm or 1-2 mm larger than the transverse arch and equal to expected stent diameter. Balloon in balloon catheter (NuMED Inc, Heart Medical Europe BV, Best, Netherlands) was used in rest. A covered or bare CP stent (NuMED CP stent, Heart Medical Europe BV, Best, the Netherlands) was hand crimped on a balloon. We coated the balloon with a little contrast medium to help the stent stick to the balloon.

We delivered the stents using the conventional back-load technique using an Amplatz super-stiff wire that was passed retrograde across the CoA with the aid of an appropriate catheter (multipurpose or right Judkins), and the soft tip of this wire was located deep in right subclavian artery. If the stent and balloon catheter were ready, the arterial sheath was exchanged over the wire for a long sheath of appropriate size for delivery of the stent.

The sheath was advanced across the CoA over the stiff wire; the balloon-mounted stent was advanced to its proper position across the coarctation site. The balloon-stent assembly was advanced through a long 11 to $14 \mathrm{~F}$ sheath (William Cook Europe, Bjaeverskov, Denmark).

An angiogram was performed through the long sheath to confirm position of the stent. When the stent was in good posi- tion, the balloon was inflated to fix the stent in the coarctation site. Once the stent was expanded properly balloon was deflated and removed out then an angiographic catheter (pigtail) was re advanced over the stiff-wire to the area proximal to the stent. A control angiogram was performed to evaluate stent position, size and to survey signs of vascular complications. Ascending, transverse and descending aortic pressures were remeasured by pullback to obtain post implantation gradient. If the stent was in a good position and size and gradient decreased enough the procedure was finished. The procedure was considered successful if the invasive gradient was reduced to $\leq 10 \mathrm{mmHg}$ and/ or the angiographic diameter had increased $\geq 50 \%$.

Acetylsalicylic acid, $100 \mathrm{mg} / d a y$, was administered for six months in all patients.

\section{Follow-up}

Routine follow-up was performed on the following day, 1 month and 6 months and yearly there after including clinical and Doppler evaluation of the femoral artery for patency, regular assessment of BP in all extremities, determination of the antihypertensive medication needs, and chestX-ray. Echocardiography including Doppler flow measurements at the CoA site was also performed. Either a computerized tomography scan or magnetic resonance imaging was planned to evaluate stent patency and possible, complications such as stent fracture, aneurysm formation after 6 months of follow-up. Computerized tomography was performed six months after the procedure in eleven patients. Angiographic restudy was not performed in any patients. Hypertension was defined as blood pressure (BP) values above the 95th percentile for height, age, and sex in children and ado- 
lescent (8). The arterial hypertension (HT) was defined as values $\geq 140 \mathrm{mmHg}$ for the systolic BP or $\geq 90 \mathrm{mmHg}$ for the diastolic BP, according to the European Society of Hypertension Guidelines applicable in 2005 (9).

\section{Statistical analysis}

The SPSS statistical program for Windows, version 15 (SPSS Inc., Chicago, Illinois, USA) was used to perform data analysis. Shapiro-Wilk test was used for the analysis of compliance with the normal distribution. Normally distributed continuous data are presented as mean \pm standard deviation (SD) and nominal variables as counts and/or percentages. Non-normal distributed continuous data are presented as median (interquartile range) and mean $\pm S D$ (ranges). In statistically comparison of Group 1 and Group 2, the (paired) Student's paired and unpaired t-tests were used for comparison of continuous variables, when normally distributed. While analyzing results of t-test, Levene test was applied for evaluation of variance homogeneity. MannWhitney $\mathrm{U}$ test was used for the abnormally distributed groups. Categorical variables were compared using Chi-square test. All statistical tests were two-sided. A p value $<0.05$ was considered statistically significant.

\section{Results}

\section{Study population (Table 1)}

Totally 45 patients had CoA were treated with stent implantation. Seven patients were postoperative surgical repair, eight had primary BAP, and four underwent both procedures, and the other 26 patients were native $\mathrm{CoA}$. In native $\mathrm{CoA}$ group one patient had functionally interrupted aortic arch, four patients had subatretic CoA.

None of the cases had special phenotypic appearance suggestive of Noonan or Williams syndrome or another genetic syndrome. There wasn't significant difference between Group 1 and Group 2 in terms of a age, gender, body mass index and hypertension ( $p>0.05$ for all).

\section{Procedural features}

Sixteen covered and 31 bare totally 47 balloon expandable $\mathrm{CP}$ stents were implanted in 45 patients. Stenting procedure was successfully completed in all patients. The covered stents were implanted in patients with PDA (4), aneurysms (2), subatretic CoA's (4) and functionally IAA (1). In two patients two stents were implanted in tandem. One of them had long aneurysm and we needed a second covered stent to adequately cover the entire lesion (Fig. 1) and in second patient we needed a covered stent after bare stent implantation to seal aortic rupture. Also, the remaining three patients were treated the covered stent because of the severity of the lesion.

Four patients had subatretic lesion and in two of them we couldn't advanced the catheter retrogradely from the coarctation site. In these two patients since the guide wire couldn't

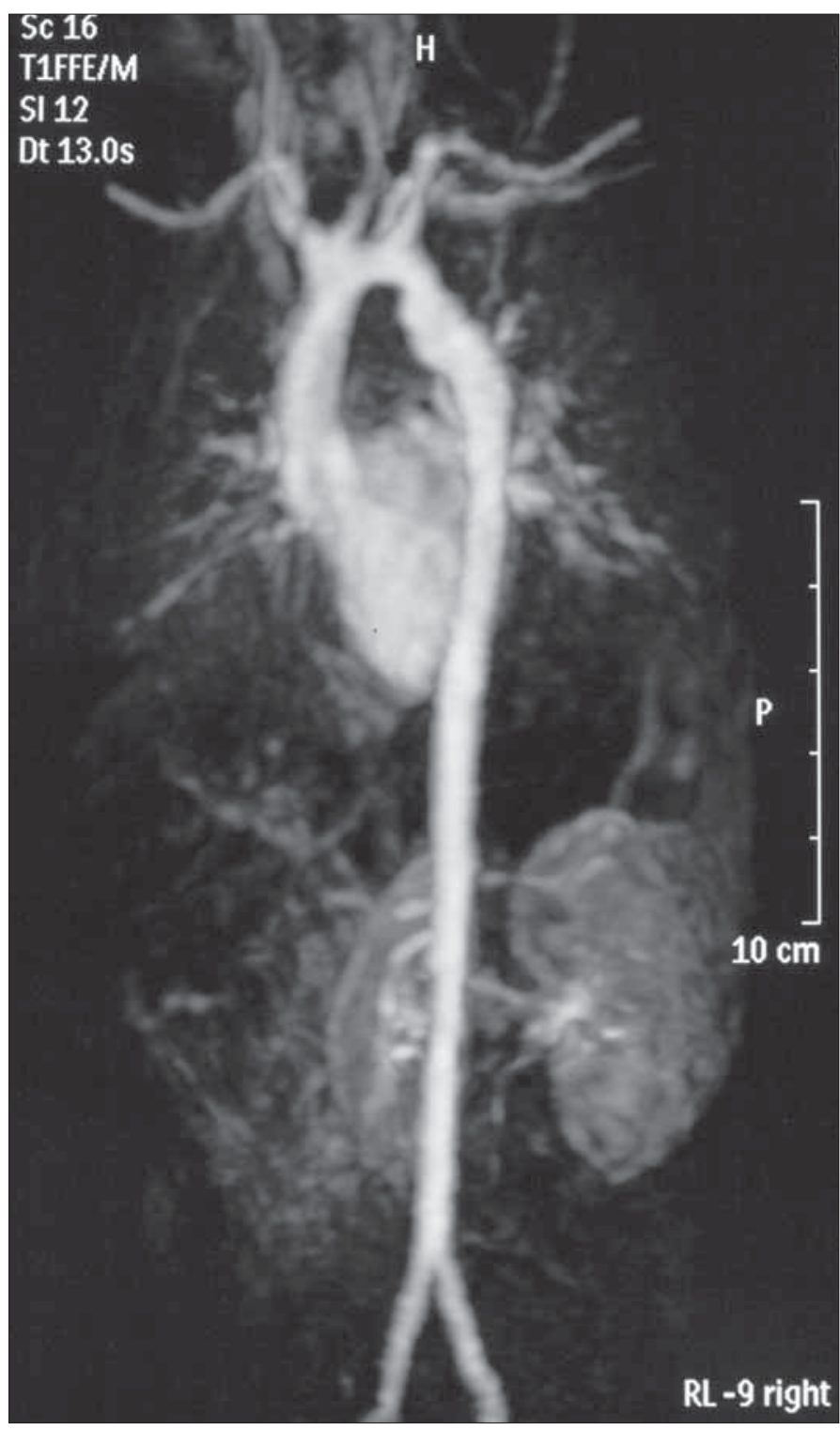

Figure 1. Aneurysm formation without recoarctation after balloon angioplasty and angiographic view of this patient after two stents implantation

pass from the coarctation site retrogradely, first radial artery cannulation and predilation with balloon were performed antegradely. In another two, although the 0.035 inch hydrophilic guide wire passed from CoA site retrogradely, the CoA site was too constricted for long sheath passage. In these patients predilation also performed retrogradely. Predilations were performed gradually with 3.5 or $4 \mathrm{~mm}$ coronary and $6 \mathrm{~mm}$ Tyshak balloons (NuMED, Hallenweg-Netherlands) (Fig. 2).

The patient who had functionally IAA, following radial artery access and with antegradely approach, fluoroscopically guided hard tip of guide wire perforation of the obstruction and creation of a neo-aortic lumen was performed. The lesion which became a severe coarctation predilated with $4 \mathrm{~mm}$ coronary and $6 \mathrm{~mm}$ Tyshak balloon. Then covered stent was implanted in a standard manner (Fig. 3). 

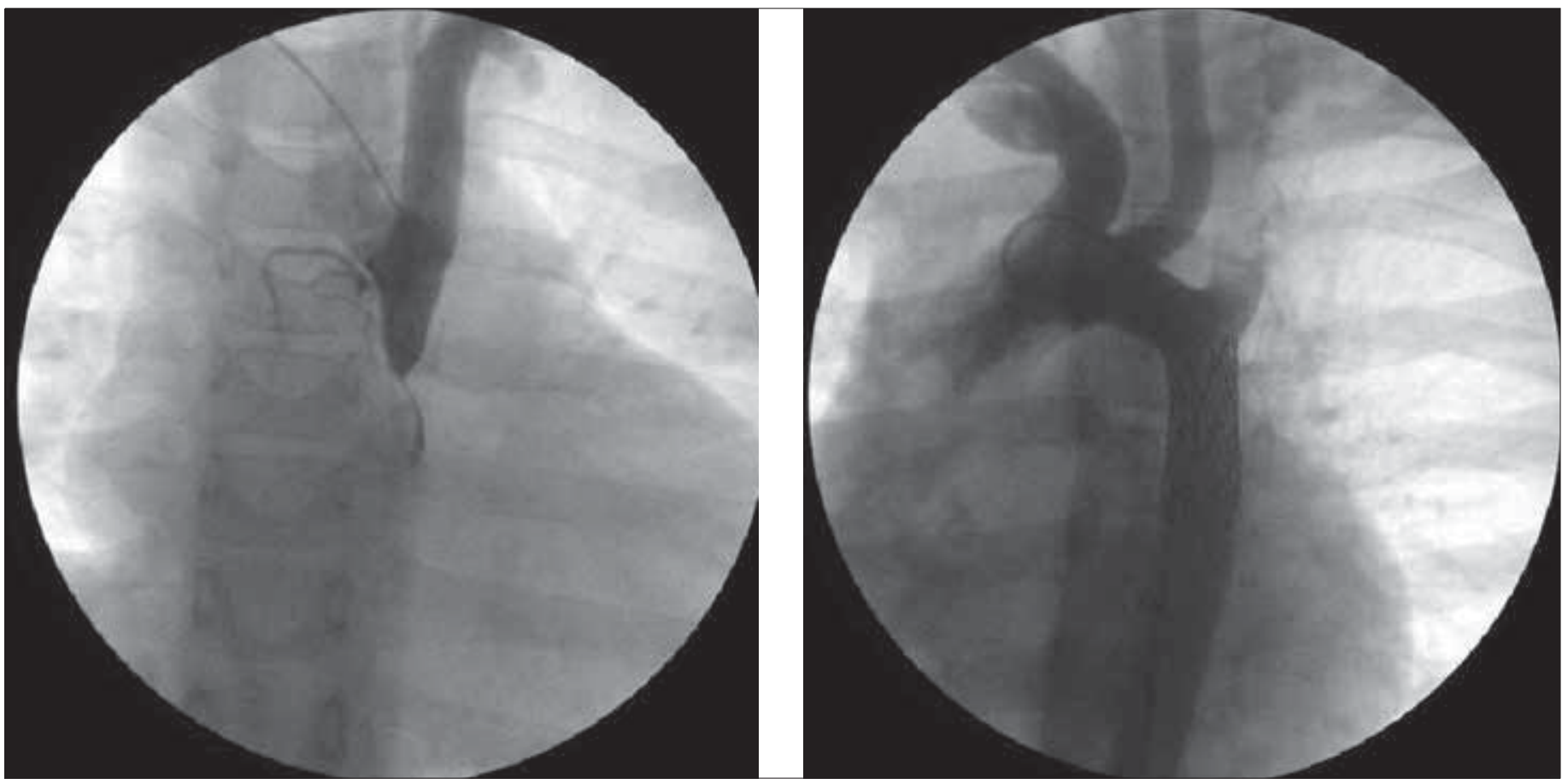

Figure 2. Angiographic appearance of subatretic coarctation of aorta before (left) and after (right) stent implantation
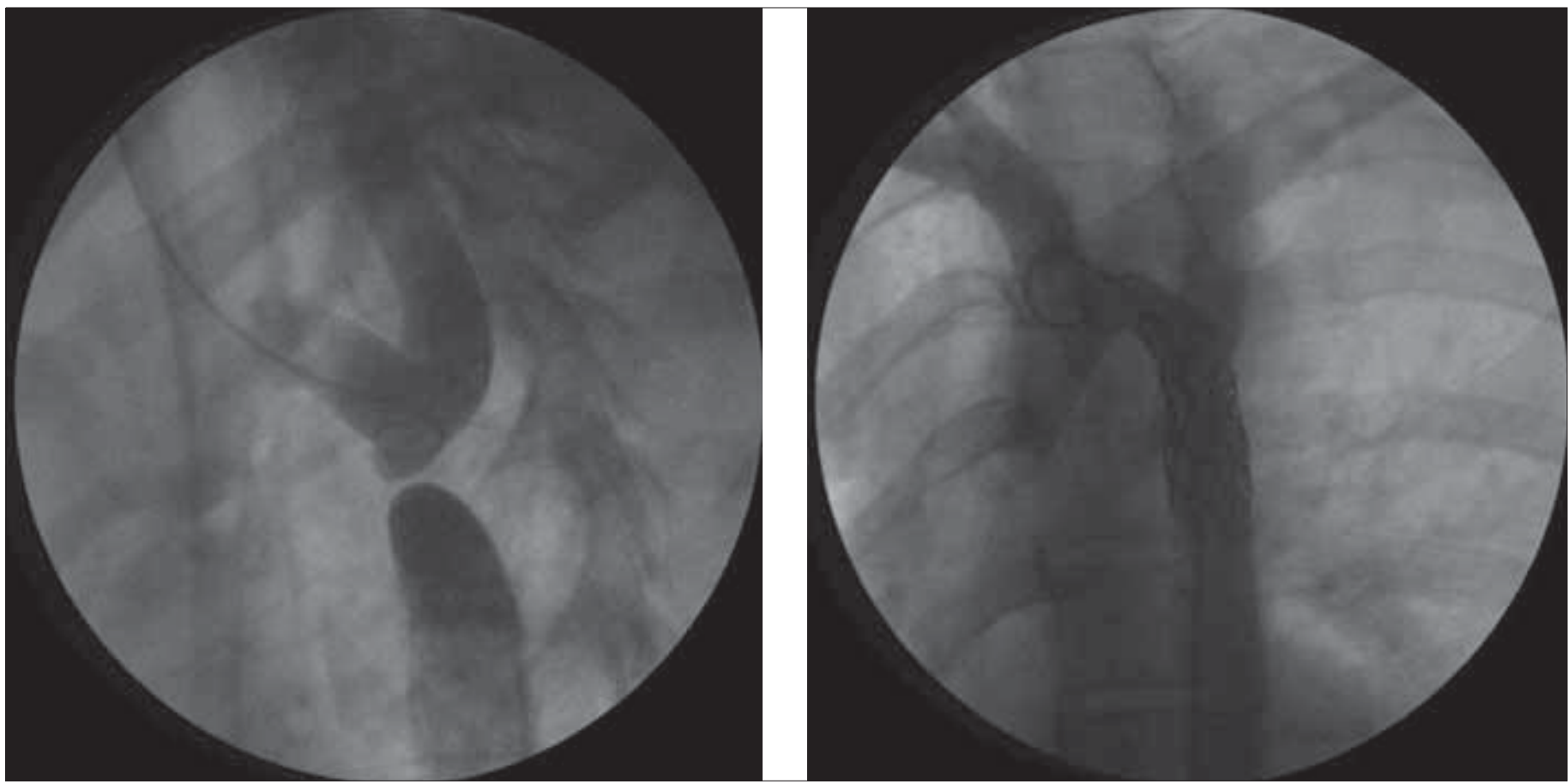

Figure 3. Angiographic appearance of functionally interrupted aortic arch before (left) and after (right) stent implantation

In two patients the lesions were on transverse arch and bare stents were implanted without any complication in these patients.

In four patients a second balloon dilation of the stent with Z-Med balloon was performed in the same session to approximate the stent to the walls of the aorta proximal to the CoA.

In three patients after placement of the pacing catheter in to the right ventricle rapid pacing of the ventricle was performed just prior to inflation of the balloon, to decrease stroke volume and blood pressure. Two of these patients had transverse arc lesions and third had moderate aortic regurgitation.

Seventy seven percent of all patients were above the hypertension limits according to ascending aortic pressure measured by catheterization immediately after the procedure. This rate was $76.9 \%$ in Group 1 (20 cases), Group 2, 78.9\% (15 cases), respectively $(p=0.6)$. 


\section{Effects of stenting on lesion characteristics and aortic gradient (Table 2)}

Considering all cases, a statistically significant decrease in both the invasive and echocardiographic gradient and statistically significant increase in lesion diameter were detected (Table 2, Fig. 4, p: $<0.001,<0.001$ and $<0.001$, respectively).

Before the procedure, the invasive gradient was significantly higher and the lesion diameter was significantly lower in Group 1 than in Group 2 ( $p=0.002$ and $p=0.005$, respectively).

The decrease in invasive and echocardiographic gradients and increase in lesion diameter is statistically significant in each group (Table 2, Fig. 4, $p<0.001, p<0.001$ and $p<0.001$ for both groups, respectively).

The percentage of decrease in gradient and increase in diameter was statistically higher in Group 1 than in Group 2 (Table 2, $p=0.04$ and $p=0.04$, respectively).

\section{Acute complications}

There was no procedure related death. There were two immediate complications relating to stenting. One patient experienced an acute wall rupture at the distal end of the implanted bare stent, which was successfully managed immediately in the same session with implantation of a second covered stent. In another patient, the stent was displaced before it was completely opened. It was carried with support of partially inflated balloon and long sheath, and repositioned in to the correct place. We used $14 \mathrm{Fr}$ sheath in three patients for femoral access we had not encountered any femoral arterial complications whereas in the remainder we used $12 \mathrm{Fr}$ or smaller sheaths with no complications and no difficulty in catheter manipulation.

None of the patients required intensive care following the procedure, and all were discharged home the following day except the patient with aortic rupture and after stenting with covered stent this patient was followed two days in intensive care unit.

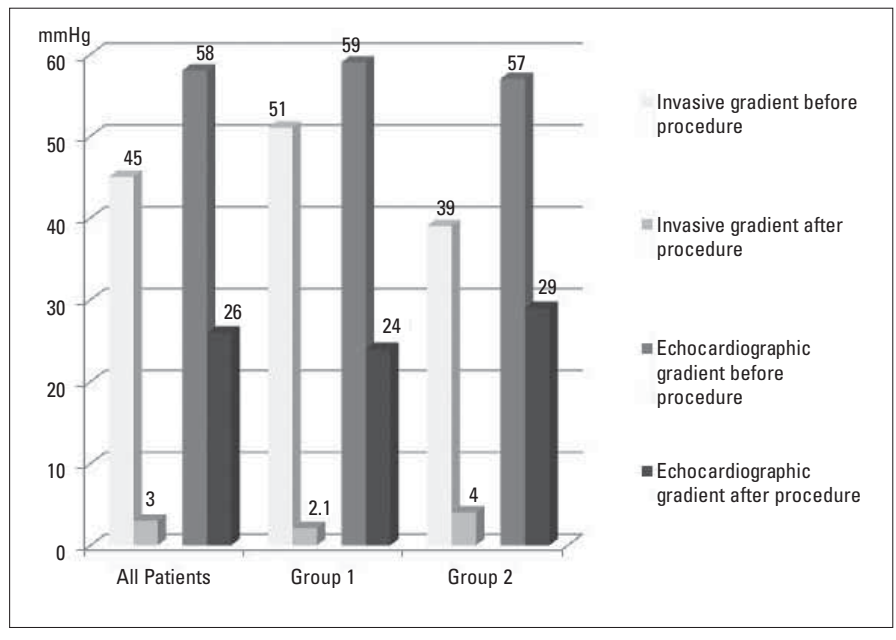

Figure 4. Alterations of the mean invasive and echocardiographic gradient

Table 2. Procedural features

\begin{tabular}{|c|c|c|c|c|c|c|}
\hline \multicolumn{2}{|l|}{ Variables } & $\begin{array}{l}\text { All patients } \\
\quad(n=45)\end{array}$ & $p^{1}$ & $\begin{array}{l}\text { Group } 1 \\
(n=26)\end{array}$ & $\begin{array}{c}\text { Group } 2 \\
(n=19)\end{array}$ & $p^{2}$ \\
\hline \multicolumn{2}{|l|}{ Stent length, mm } & $32 \pm 8(16-45)$ & & $32 \pm 7(22-45)$ & $30 \pm 9(16-45)$ & 0.5 \\
\hline \multicolumn{2}{|l|}{ Balloon size, $\mathrm{mm}$} & $15 \pm 2(10-20)$ & & $15 \pm 3(10-20)$ & $14 \pm 2(12-20)$ & 0.8 \\
\hline \multicolumn{2}{|c|}{ Utilization rate of covered stent, $\mathrm{n}(\%)$} & $16(35.5)$ & & $9(34.6)$ & $7(36.8)$ & 0.9 \\
\hline \multirow{2}{*}{$\begin{array}{l}\text { Invasive } \\
\text { gradient, } \mathrm{mmHg}\end{array}$} & Pre-stent & $45 \pm 23(20-150)$ & $<0.001$ & $51.4 \pm 30(19-62)$ & $39 \pm 9.6(18-50)$ & 0.002 \\
\hline & Post-stent & $\begin{array}{c}1(4) \\
3 \pm 3.6(0-10)\end{array}$ & & $\begin{array}{c}0(3) * \\
2.1 \pm 3.4(0-13)\end{array}$ & $\begin{array}{c}2(6)^{* *} \\
4 \pm 4.1(0-26)\end{array}$ & 0.08 \\
\hline \multicolumn{2}{|c|}{ Invasive gradient decrease, $\%$} & $\begin{array}{c}98(13.5) \\
91 \pm 12(36-100)\end{array}$ & & $\begin{array}{c}100(11) \\
94 \pm 8(69-100)\end{array}$ & $91 \pm 8(75-100)$ & 0.04 \\
\hline \multirow[t]{2}{*}{ Diameter lesion, mm } & Pre-stent & $6.9 \pm 3.4(3-13)$ & $<0.001$ & $5.5 \pm 2.8(3-13)$ & $8.3 \pm 3.2(4.8-13)$ & 0.005 \\
\hline & Post-stent & $13.8 \pm 3.4(9-20)$ & & $14.5 \pm 3.2(9-20) *$ & $14 \pm 2.5(10-18) * *$ & 0.7 \\
\hline \multicolumn{2}{|l|}{ Diameter increase, $\%$} & $45 \pm 17(13-76)$ & & $57 \pm 22(13-76)$ & $40 \pm 14(18-60)$ & 0.04 \\
\hline \multicolumn{2}{|l|}{ Mean procedure time } & $97 \pm 37(30-210)$ & & $102 \pm 43(45-150)$ & $93 \pm 29(35-120)$ & 0.4 \\
\hline \multicolumn{2}{|l|}{ Mean fluoroscopy time } & $24 \pm 14(11-44)$ & & $26 \pm 16(18-35)$ & $23 \pm 10(11-35)$ & 0.4 \\
\hline \multirow[t]{2}{*}{$\begin{array}{l}\text { Echocardiographic } \\
\text { gradient, } \mathrm{mmHg}\end{array}$} & Pre-stent & $\begin{array}{c}52(12) \\
58 \pm 15(30-103)\end{array}$ & $<0.001$ & $59 \pm 16(40-78)$ & $\begin{array}{c}51(11) \\
57 \pm 14(38-98)\end{array}$ & 0.5 \\
\hline & Post-stent & $\begin{array}{c}25(10) \\
26 \pm 10(8-51)\end{array}$ & & $24 \pm 9(10-46) *$ & $29 \pm 12(10-51) *$ & 0.2 \\
\hline \multicolumn{2}{|l|}{ Success rate, $\%$} & 100 & & 100 & 100 & \\
\hline \multicolumn{7}{|c|}{$\begin{array}{l}\text { - Values are expressed as mean } \pm \text { standard deviations (ranges), median (interquartile range) and numbers (percentages) } \\
\text { - } 1 \text { 1- paired Student's t-test for comparison of post-stent versus pre-stent values for all patients, } \mathrm{p2} \text { - Mann-Whitney U, unpaired Student's t and Chi-square tests for comparison of Group } \\
1 \text { and Group } 2 \text { values } \\
\text { •*-paired Student's t-test - } p<0.001 \text { for comparison of post-stent versus pre-stent values within groups }\end{array}$} \\
\hline
\end{tabular}




\section{Follow-up}

The mean follow-up duration was $12.1 \pm 7.1$, median 11 month (2-29). While mean invasive gradient decreased from $44 \pm 4$ $\mathrm{mmHg}$ (range $37-50$ ) to $2 \pm 2$ (range $0-7$ ) mmHg, mean echocardiographic gradient measured one day after procedure was $26 \pm 7$ $\mathrm{mmHg}$ (range 20-39) and there was no the diastolic run-off in echocardiographic examination. Follow-up echocardiographic examination of these patients revealed there was no statistically significant difference between echocardiographic gradient measured at 24-hour after procedure and first $(29 \pm 10,10-45$ $\mathrm{mmHg})$ and 6 months $(32 \pm 19,10-47 \mathrm{mmHg})$ control measurements ( $p>0.05$ for all).

Following stent implantation, five patients (one patient $3.8 \%$ ) in Group 1 and 4 patients (21\%) in Group 2, ( $p=0.01)$ remained hypertensive requiring antihypertensive medication at a mean follow-up of 12.1 month.

Eleven patients had a follow-up contrast CT scan at 6 month and none of them had any evidence of an endovascular leak, dissection, or aneurysm. Results of examination including measurement of upper and lower extremity arterial tension, echocardiography and CT during follow-up period demonstrated that no patient required redilation, no recurrence of the $\mathrm{CoA}$ and no evidence of dissection or aneurysm formation.

\section{Discussion}

This study shows transcatheter treatment of CoA in older children, adolescents and adults with stenting results in immediate hemodynamic benefit. The stenting procedure was successfully completed in all patients. Our results are supported by other studies, with acute success rates approaching 100\% (7). We have successfully utilized CP stents in the management of both native and reCoA. In both groups, stenting increased diameter of $\mathrm{CoA}$ site and reduced invasive gradient significantly. Also the arm to-leg systolic gradient fell sufficiently. These findings point to a good relief of the obstruction. In addition, we have also demonstrated the efficacy and durability of covered stents to treat aneurysmal dilatation and $\mathrm{CoA}$ and PDA associations. There was no mortality related to the CoA during the transcatheter procedure or during the follow up period.

Nowadays, both the subatretic CoAs and even the functionally IAA are treated successfully using intravascular stent. In mentioned pathologies, if the stenosis is very severe or totally obstructed with anatomical continuity, a two-stage approach could be advocated, with repeated procedure at approximately six months $(10,11)$. During this time, a scar forms in the area of previous angioplasty, and then stent implantation and redilation is performed securely. However, predilation first and then stenting could also be performed at the same session (12-15). In our study, there were the subatretic native CoA's in four cases and one patient had a functionally IAA. Covered stent implantation was performed successfully in all these cases. Predilation with the coronary and small Tyshak balloon were performed before stenting. We performed stent implantations without prior immediate balloon angioplasty except in these five patients. Implantation directly without predilation not only shortens the procedure time but also possibly reduces the complication of acute dissection as it reduces the amount of catheter and wire manipulation across the unguarded freshly angioplasty-dilated site. However, in some cases, predilation is becoming a necessity since the coarctation site is so narrow and does not permit long sheath passage.

It is possible to decrease stroke volume, blood pressure, and pulse pressure significantly, just prior to inflation of the balloon either by administering drugs such as adenosine, esmolol or by rapidly pacing the right ventricle with a pacing catheter $(16,17)$. We applied rapid right ventricular pacing in two patients with transverse arcus lesion and in a patient with aortic regurgitation. Stenting of correct place is more important in transverse arcus lesion because of origin of large cranial vessels.

Although overall anatomical and hemodynamic results of stent implantation are satisfactory, CoA stenting is not without risk. Aortic rupture, stent fracture, embolization or displacements of stent are infrequent complications of stent implantation (18-21).

Aortic disruption can be a potentially catastrophic complication of $\mathrm{CoA}$ stenting $(7,22,23)$. This complication occurred in one of the 45 patients in our study; however, deployment of a second covered stent successfully excluded the area of disruption from the circulation. We believe that a covered stent should be readily available in the catheterization laboratory when CoA stenting is being performed. Some authors even claim to use covered stents as the primary implant to prevent this complication especially in elderly patients which have propensity to aortic rupture because of calcifications $(24,25)$.

Stent migration is also one of the most frequently encountered technical complications. The incidence is declared (28/588) $4.8 \%$ in a multicenter retrospective series (7). Stent migration can result from balloon under sizing or over sizing or from balIoon rupture. Nearly half of the migrated stent repositioned and do not require any further intervention $(7,26,27)$. Also some of them could be positioned suboptimal place in that case another stent is needed to cover true lesion. In one of our cases the stent was displaced before it was completely opened. It was carried with support of half inflated balloon and long sheath, and repositioned in to the correct place then fully inflated.

The incidence of peripheral vascular complications after stenting is $2-5 \%$ in literature. The complication is related with the size of arterial access sheaths required and patient's age. How big the arterial sheath is required and how small the patient's age and weight the complication risk increases $(7,24,28)$. On the other hand, covered stent implantation requires a large delivery system. Recently, covered stents having low profile delivery system have been developed and studies with good results were reported with them (29). Although we used also $14 \mathrm{~F}$ sheath in 
three adult patients we had not encountered any femoral arterial complications. However, both in small aged patients to prevent vascular complications, as well as in subatretic, very narrow cases to eliminate need for predilation this kind of new generation covered stents may be preferred.

The $\mathrm{BP}$ reduction is a major goal in treatment of $\mathrm{CoA}(30)$. In our study, stenting was successful in all patients. In addition, the arm to leg systolic gradient fell sufficiently. These findings both point to a good relief of the obstruction. However, five of 45 patients are hypertensive requiring antihypertensive medication; all are older than 14 years old. After successful stenting, improvement in HT occurs in most patients (31). However, HT may persist after $\mathrm{CoA}$ stenting in adult life, probably due to structural and functional abnormalities of the arterial wall, which can result in diminished arterial wall compliance and increased rigidity $(30,32)$. Long-standing $\mathrm{HT}$ in these patients may be an important factor in persistence of HT despite successful stenting.

Most cases of isolated native or reCoA are suitable for stent implantation in patients over $20 \mathrm{~kg}$. However, complex cases such as those with additional cardiac abnormality (significant valvular regurgitations), with large aneurysms (maximum CP stent diameter $24 \mathrm{~mm}$ ), or femoral arterial problems related with previous interventions $\mathrm{CoA}$ repair are better managed by surgery. Also in cases of interruption other than membranous atresia with a gap between ascending and descending aorta, surgery must be the first choice (33).

\section{Study limitations}

Some limitations have to be noted about this study. Firstly, we need a greater number of patients have undergone stent implantation and their long-term results. Secondly, our population included both children and adult. Thirdly, this was a single-centre report and patients were not compared with surgery or BAP alone. Fourthly, 24-hour ambulatory blood pressure monitoring before stenting was not performed in any patients. Finally, radiologic imaging for aneurysm was done in limited number of patients after procedure.

\section{Conclusion}

Endovascular stenting for native and reCoA of the aorta in older children and adults appears to be an acceptable treatment. This conclusion is supported by our finding of effective relief of the CoA gradients and increasing lesion diameters in both native and recurrent coarctation. However, some serious complications do occur and HT remains in some patients. Aortic disruption and stent displacement are potentially catastrophic complications of stenting but implanting a second covered stent can seal the ruptured wall and parking in a safe area or replacement of displaced stent carried by half-inflated balloon could solve the problem. Continued follow-up, to assess long-term results of stent implantation is warranted.

\section{Acknowledgement}

The authors thank to Assoc. Prof. Dr. Ahmet Topuzoğlu for statistical procedure control.

Conflict of interest: None declared.

\section{References}

1. Mendelsohn AM, Lloyd TR, Crowley DC, Sandhu SK, Kocis KC Beekman RH 3rd. Late follow-up of balloon angioplasty in children with a native coarctation of the aorta. Am J Cardiol 1994; 74: 696-700.

2. Rao PS, Thapar MK, Kutayli F, Carey P. Causes of recoarctation after balloon angioplasty of unoperated aortic coarctation. J Am Coll Cardiol 1989; 13: 109-15.

3. Fawzy ME, Sivanandam V, Galal O, Dunn B, Patel A, Rifai A, et al. One- to ten-year follow-up results of balloon angioplasty of native coarctation of the aorta in adolescents and adults. J Am Coll Cardiol 1997; 30: 1542-6.

4. Koerselman J, de Vries H, Jaarsma W, Muyldermans L, Ernst JM, Plokker HW. Balloon angioplasty of coarctation of the aorta: a safe alternative for surgery in adults: immediate and mid-term results. Catheter Cardiovasc Interv 2000; 50: 28-33.

5. O'Laughlin MP, Perry SB, Lock JE, Mullins CE. Use of endovascular stents in congenital heart disease. Circulation 1991; 83: 1923-39.

6. Suarez de Lezo J, Pan M, Romero M, Medina A, Segura J, Pavlovic $D$, et al. Balloon-expandable stent repair of severe coarctation of aorta. Am Heart J 1995; 129: 1002-8.

7. Forbes TJ, Garekar S, Amin Z, Zahn EM, Nykanen D, Moore P, et al. Procedural results and acute complications in stenting native and recurrent coarctation of the aorta in patients over 4 years of age: a multi-institutional study. Catheter Cardiovasc Interv 2007; 70: 276-85.

8. Rosner B, Prineas RJ, Loggie JM, Daniels SR. Blood pressure nomograms for children and adolescents by height, sex, and age, in the United States. J Pediatr 1993; 123: 871-86.

9. European Society of Hypertension-European Society of Cardiology Guidelines Committee. 2003 European Society of HypertensionEuropean Society of Cardiology guidelines for the management of arterial hypertension. J Hypertens 2003; 21: 1011-53.

10. Butera G, Piazza L, Chessa M, Abella R, Bussadori C, Negura D, et al. Covered stents in patients with congenital heart defects. Catheter Cardiovasc Interv 2006; 67: 466-72.

11. Kusa J, Szkutnik M, Bia kowski J. Percutaneous reconstruction of the continuity of a functionally interrupted aortic arch using a stent. Cardiol J 2008; 15: 80-4.

12. Thanopoulos BD, Hadjinikolaou L, Konstadopoulou GN, Tsaousis GS, Triposkiadis F, Spirou P. Stent treatment for coarctation of the aorta: intermediate term follow up and technical considerations. Heart 2000; 84: 65-70.

13. Zabal C, Attie F, Rosas M, Buendia-Hernandez A, Garcia-Montes JA. The adult patient with native coarctation of the aorta: balloon angioplasty or primary stenting? Heart 2003; 89: 77-83.

14. Chessa M, Carrozza M, Butera G, Piazza L, Negura DG, Bussadori $\mathrm{C}$, et al. Results and mid-long-term follow-up of stent implantation for native and recurrent coarctation of the aorta. Eur Heart J 2005; 26: 2728-32.

15. Bruckheimer E, Dagan T, Amir G, Birk E. Covered CheathamPlatinum stents for serial dilation of severe native aortic coarctation. Catheter Cardiovasc Interv 2009; 74: 117-23.

16. Golden $A B$, Hellenbrand WE. Coarctation of the aorta: stenting in children and adults. Catheter Cardiovasc Interv 2007; 69: 289-99. 
17. Sivaprakasam MC, Veldtman GR, Salmon AP, Cope R, Pierce T, Vettukattil JJ. Esmolol-assisted balloon and stent angioplasty for aortic coarctation. Pediatr Cardiol 2006; 27: 460-4.

18. Bulbul ZR, Bruckheimer E, Love JC, Fahey JT, Hellenbrand WE. Implantation of balloon-expandable stents for coarctation of the aorta: implantation data and short-term results. Cathet Cardiovasc Diagn 1996; 39: 36-42.

19. Ebeid MR, Prieto LR, Latson LA. Use of balloon-expandable stents for coarctation of the aorta: initial results and intermediate-term follow-up. J Am Coll Cardiol 1997; 30: 1847-52.

20. Suarez de Lezo J, Pan M, Romero M, Medina A, Segura J, Lafuente $M$, et al. Immediate and follow-up findings after stent treatment for severe coarctation of the aorta. Am J Cardiol 1999; 83: 400-6.

21. Magee AG, Brzezinska-Rajszys $G$, Qureshi SA, Rosenthal $E$, Zubrzycka M, Ksiazyk J, et al. Stent implantation for aortic coarctation and recoarctation. Heart 1999; 82: 600-6.

22. Tan JL, Mullen M. Emergency stent graft deployment for acute aortic rupture following primary stenting for aortic coarctation. Catheter Cardiovasc Interv 2005; 65: 306-9.

23. Varma C, Benson LN, Butany J, McLaughlin PR. Aortic dissection after stent dilatation for coarctation of the aorta: a case report and literature review. Catheter Cardiovasc Interv 2003; 59: 528-35.

24. Tanous D, Collins N, Dehghani P, Benson LN, Horlick EM. Covered stents in the management of coarctation of the aorta in the adult: initial results and 1-year angiographic and hemodynamic followup. Int J Cardiol 2010; 140: 287-95.
25. Hijazi ZM. Catheter intervention for adult aortic coarctation: be very careful! Catheter Cardiovasc Interv 2003; 59: 536-7.

26. Amirghofran AA, Peiravian F, Borzoee M, Emaminia A, Mollazadeh $\mathrm{R}$. A wandering stent in the ascending aorta. J Cardiovasc Med 2008; 9: 969-70.

27. Hornung TS, Benson LN, McLaughlin PR. Interventions for aortic coarctation. Cardiol Rev 2002; 10: 139-48.

28. Carr JA. The results of catheter-based therapy compared with surgical repair of adult aortic coarctation. J Am Coll Cardiol 2006; 47: 1101-7.

29. Bruckheimer E, Birk E, Santiago R, Dagan T, Esteves C, Pedra CA. Coarctation of the aorta treated with the Advanta V12 large diameter stent: acute results. Catheter Cardiovasc Interv 2010; 75: 402-6.

30. Moltzer E, Roos-Hesselink JW, Yap SC, Cuypers JA, Bogers AJ, de Jaegere $\mathrm{PP}$, et al. Endovascular stenting for aortic (re)coarctation in adults. Neth Heart J 2010; 18: 430-6.

31. Hamdan MA, Maheshwari S, Fahey JT, Hellenbrand WE. Endovascular stents for coarctation of the aorta: initial results and intermediate-term follow-up. J Am Coll Cardiol 2001; 38: 1518-23.

32. Gardiner HM, Celermajer DS, Sorensen KE, Georgakopoulos D, Robinson J, Thomas 0 , et al. Arterial reactivity is significantly impaired in normotensive young adults after successful repair of aortic coarctation in childhood. Circulation 1994; 89: 1745-50.

33. Ramnarine I. Role of surgery in the management of the adult patient with coarctation of the aorta. Postgrad Med J 2005; 81: 243-7. 